\title{
THE EFFECT OF INFECTION AND TRAUMA ON THE EXCRETION OF URINARY CORTIN ${ }^{1}$
}

\author{
BY REGINALD A. SHIPLEY, RALPH I. DORFMAN, ETHEL BUCHWALD, \\ AND ETHELREDA ROSS \\ (From the Lakeside Hospital, and the Departments of Medicine and Biochemistry, Western \\ Reserve University School of Medicine, Cleveland)
}

(Received for publication February 25, 1946)

Adrenal cortical hyperplasia which is known to occur during infection and after trauma $(1,2)$ suggests the occurrence of a corresponding increase in the physiological activity of the gland. Scant information is available, however, bearing directly on the functional status of the adrenal cortex during conditions of stress. It would be important to know not only whether periods of stress are accompanied by increased cortical function, but also whether recovery might be influenced by the functional state of the adrenal cortex, and whether such conditions as post-infectious asthenia might be attributable to adrenal exhaustion resulting from extreme stimulation during the active phase of the disease.

Although the excretion of neutral 17-ketosteroids is influenced by adrenal cortical function, the chemical determination of these steroids affords a poor measure of the activity of the gland, inasmuch as the adrenal is not the sole source of the compounds in this fraction. Moreover, information as to the precursors of urinary 17-ketosteroids is far from complete. The one classical precursor, testosterone, has insignificant cortinlike activity.

Browne and coworkers demonstrated the presence of cortin-like activity in the urine of postoperative patients and patients suffering infection or other types of stress, but were not able to detect the material in normal urine ( $3 a$ and $b)$. Evidence has recently been adduced that the substance is present in the urine of normal men and women who have not been subjected to stress, and that it possesses the physiological properties of cortical hormone when tested by a great variety of methods (4 to 9). Furthermore, the material has been ob-

1 The work described in this paper was done under a contract recommended by the Committee on Medical Research, between the Office of Scientific Research and Development and University Hospitals of Cleveland. served to disappear from the urine of monkeys after adrenalectomy, but not after gonadectomy (10), and activity has not been detectable in the urine of patients with Addison's disease (11). It may therefore be assumed with justification that the urinary substance has its origin in the adrenal cortex, and that its rate of excretion should be influenced by variations in cortical function.

The intent of the work herein reported was to determine the urinary cortin output of human subjects in the normal state, during stress, and during recovery from stress. It was considered desirable to employ methods which would allow expression of cortin values in terms of a pure cortical hormone, rather than as arbitrary biological units. These studies are a part of a broader investigation of the physiology and chemistry of active urinary cortical hormones.

\section{METHODS}

Preparation of extracts. Urine samples were collected in 48-hour lots, and were preserved with toluene. The $\mathrm{pH}$ varied from approximately 5.5 to 6.5 . One-fourth volume of ethylene dichloride was added, and after being shaken for 2 minutes in a mechanical shaker, the ethylene dichloride was separated from the urine with a Sharples centrifuge. The urine was extracted twice more with the same volume of ethylene dichloride and the 3 extracts pooled and evaporated in vacuo at an internal temperature below $40^{\circ} \mathrm{C}$. After twice adding 95 per cent ethanol and evaporating to dryness to remove residual ethylene dichloride, the residue was taken up in $50 \mathrm{ml}$. chloroform, cooled in an ice bath and washed 3 times with $0.1 \mathrm{~N} \mathrm{NaOH}$. Each washing of $\mathrm{NaOH}$ was backwashed with $5 \mathrm{ml}$. of chloroform. All chloroform fractions were pooled and washed with $5 \mathrm{ml} . \mathrm{H}_{2} \mathrm{O} 4$ times, or until free from $\mathrm{NaOH}$. The chloroform was evaporated in vacuo, and the residue was taken up in 95 per cent ethanol and stored at $-15^{\circ} \mathrm{C}$. until used. Under these conditions there appeared to be no loss of activity for at least 4 months.

Methods of assay. Two methods of assay were employed. One method was based upon the protection of adrenalectomized rats to exposure to cold. The other 
made use of the glycotropic activity exhibited by certain cortical hormones. Reported elsewhere are details of the methods along with a critical appraisal of their reliability $(12,13)$.

The cold test is the simplest and most sensitive method now available for the assay of cortin-like substances. A $10 \mathrm{ml}$. portion of normal urine contains sufficient active material to exert a protective effect on a rat. The response shows a gradation in relation to dose, and may be expressed in the form of a log-dose response curve. The initial straight line portion of the curve is very short, however, and in the case of urine extracts at levels beyond 4 times the minimal effective dose the response declines. The most serious defect of the method is an unexplained variability of sensitivity of test animals from lot to lot. In only about 2 out of 3 trials will a group of rats show sufficient reactivity for satisfactory assay.

The application of the method was as follows: One hundred rats divided into groups of 10 were run simultaneously. One group served as control, 1 received $64 \gamma$ of compound $A$ of Kendall (11-dehydrocorticosterone ${ }^{2}$ ), and

2 We are indebted to Dr. E. C. Kendall for the greater part of the supply of 11-dehydrocorticosterone used in these studies.

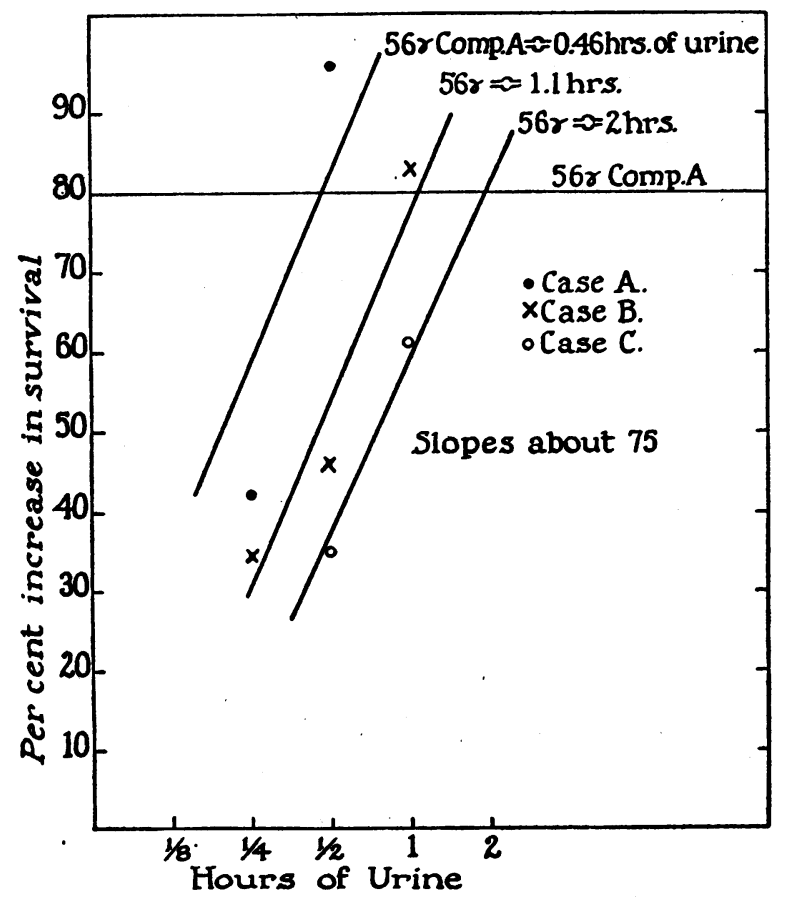

Fig. 1. Cold Test

Nine groups of 10 animals each were run simultaneously, with 1 group serving as untreated controls, and another receiving $56 \gamma$ of compound $A$. The point is noted at which a line for a urine sample crosses the horizontal line representing the response to compound $A$. The abscissal value of this point represents the equivalent in hours of urine which is comparable in activity of $56 \mathrm{\gamma}$ of compound $A$. the others received urinary extract in doses equivalent to from $1 / 4$ to 1 hour of urine output. Each urine sample was administered at a minimum of 2 different dose levels. If the group receiving compound $\mathrm{A}$ survived at least 20 per cent longer than the control group, and if the 2 dose levels of urine extract followed a rising curve, the results were considered satisfactory for calculation of potency (Figure 1). Inasmuch as the sensitivity of various lots of animals is variable, the slope of the response curve is likewise variable, and the error of an assay cannot be predicted in advance. When 2 dose levels of unknown are used, and when sensitivity is maximal, the limits of error are $1 / 3$ as great, or 3 times greater than the observed value with $p=0.05$. When sensitivity is at the lowest accepted level ( 20 per cent increase to $64 \gamma$ of compound A) these limits are $1 / 6$ and 6 . Inasmuch as the slope, furthermore, must be estimated for each assay, it is clear that values which were obtained by the cold test method were rough estimations.

The glycogen test as employed for assay is about $1 / 4$ as sensitive as the cold test, and is rather laborious, but is more reproducible and subject to less error. There is a long rising portion of the log-dose response curve without a decline at higher dose levels, and there is no indication of a lack of sensitivity of animals from group to group.

In the use of this assay, 8 to 10 mice received a given dose of urine extract (usually 3 hours of urine equivalent). The mouse livers were pooled and the glycogen content of the pooled sample determined. Potency of an extract was estimated by reference to a standard curve obtained by the administration of graded doses of compound $\mathrm{A}$ (11-dehydrocorticosterone) to a series of 193 mice. The usual limits of error of an assay $(p=0.05)$ were calculated to be 3 times higher, or $1 / 3$ as great as the observed value (error factor of 3 ).

\section{RESULTS}

The cortin content of normal urine. A pooled sample of male urine $(\mathrm{N}-197)$, when assayed against compound $\mathrm{A}$, gave a value of $0.6 \mathrm{mgm}$. per liter by the cold test, and $0.4 \mathrm{mgm}$. by the glycogen test. The error factor of the latter was 1.6 with $p=0.05$, and 1.9 with $p=0.01$. The assay curves of compound $A$ and pooled normal urine are illustrated in Figure 2. The details of these comparisons are recorded elsewhere $(12,13)$.

In Table $I$ are listed assays on 17 normal subjects, ranging in age between 24 and 38 years. Nothing suggestive of a difference between males and females may be discerned from the data. The cold test tended to give higher values than the glycogen test. In the case of the former, the range was between 0.5 and $1.8 \mathrm{mgm}$. compound $A$ equivalent per day, with an average of $1.1 \mathrm{mgm}$.; in the case of the latter, the values ranged from 
$<0.2 \mathrm{mgm}$. to $0.8 \mathrm{mgm}$., and averaged less than $0.4 \mathrm{mgm}$.

It is seen that with both pooled urine and with

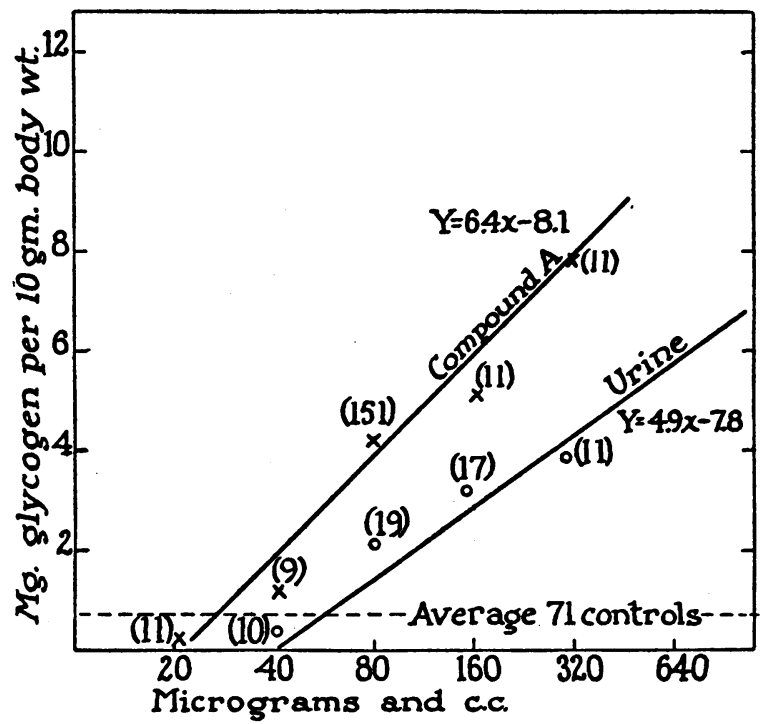

Fig. 2. Glycogen Test

The regression line on the right represents the response to a sample of pooled normal urine when administered at 4 different dose levels. In the assay of individual samples as described in the text, 1 dose level was used and the dose was expressed as hours of urine. Potency of the urine sample was calculated by noting the point on the line for compound $\mathrm{A}$ which gave the same glycogen value as the sample of urine.
TABLE I

Cortin excretion in normal subjects

\begin{tabular}{|c|c|c|c|}
\hline $\begin{array}{l}\text { Method } \\
\text { of } \\
\text { assay }\end{array}$ & Sex & $\begin{array}{c}\text { Hours } \\
\text { of urine } \\
\text { per animal }\end{array}$ & $\begin{array}{c}\text { Cortin } \\
\text { excretion } \\
\text { compound A-equiv. }\end{array}$ \\
\hline Cold test & $\begin{array}{l}\mathbf{F} \\
\mathbf{M} \\
\mathbf{M} \\
\mathbf{M} \\
\mathbf{F} \\
\mathbf{M} \\
\mathbf{M}\end{array}$ & 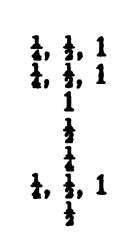 & $\begin{array}{c}\text { mem. por day } \\
1.4 \\
0.7 \\
0.5 \\
1.0 \\
1.5 \\
1.8 \\
1.0\end{array}$ \\
\hline $\begin{array}{l}\text { Liver glycogen } \\
\text { test }\end{array}$ & $\begin{array}{l}\mathbf{M} \\
\mathbf{M} \\
\mathbf{M} \\
\mathbf{F} \\
\mathbf{F} \\
\mathbf{F} \\
\mathbf{M} \\
\mathbf{M} \\
\mathbf{F} \\
\mathbf{M} \\
\mathbf{M} \\
\mathbf{F}\end{array}$ & $\begin{array}{l}3 \\
3 \\
2 \\
2 \\
2 \\
4 \\
4 \\
4 \\
4 \\
2 \\
4 \\
4\end{array}$ & $\begin{array}{r}<0.3 \\
<0.3 \\
0.5 \\
<0.5 \\
0.8 \\
0.5 \\
0.4 \\
<0.2 \\
<0.2 \\
<0.5 \\
0.3 \\
<0.2\end{array}$ \\
\hline
\end{tabular}

individual assays the cold test gave higher values than the glycogen test. This difference, if not due to a chance error of the assays, may be due to the presence in the urine of steroids which have relative activities in the 2 tests differing from those of compound A. Desoxycorticosterone, for example, is much less active in its effect on liver glycogen than it is in the cold test.

TABLE II

Cortin excretion as affected by infectious disease

\begin{tabular}{|c|c|c|c|c|c|c|c|c|c|c|c|c|c|}
\hline \multirow{3}{*}{ Case } & \multirow{3}{*}{ Sex } & \multirow{3}{*}{ Age } & \multirow{3}{*}{ Diagnosis } & \multirow{3}{*}{$\begin{array}{l}\text { Maxi- } \\
\text { mum } \\
\text { fever }\end{array}$} & \multirow{3}{*}{$\begin{array}{l}\text { Dura- } \\
\text { tion } \\
\text { of } \\
\text { fever }\end{array}$} & \multirow{3}{*}{ Treatment } & \multirow{3}{*}{$\begin{array}{c}\text { Type } \\
\text { of } \\
\text { assay }\end{array}$} & \multicolumn{6}{|c|}{ Cortin excretion compound A equiv. } \\
\hline & & & & & & & & \multicolumn{2}{|c|}{ Active phase } & \multicolumn{2}{|c|}{ Early convalescence } & \multicolumn{2}{|c|}{ Late convalescence } \\
\hline & & & & & & & & Range & $\begin{array}{c}\text { Aver- } \\
\text { age }\end{array}$ & Range & $\begin{array}{c}\text { Aver- } \\
\text { age }\end{array}$ & Range & $\begin{array}{l}\text { Aver- } \\
\text { age }\end{array}$ \\
\hline H. M. & $\mathbf{M}$ & 22 & Lobar pneumonia & 40.8 & $\begin{array}{c}\text { days } \\
5\end{array}$ & Penicillin & $\begin{array}{l}\text { C. T.* } \\
\text { L. G.t }\end{array}$ & $\begin{array}{r}\text { mgm. per day } \\
0.6 \text { to } 3.2 \\
0.5 \text { to } 3.1\end{array}$ & \begin{tabular}{|c|} 
mgm \\
per \\
day \\
1.8 \\
1.8
\end{tabular} & $\begin{array}{r}\text { mgm. per day } \\
1.4 \text { to } 1.6 \\
0.5 \text { to } 5.7\end{array}$ & $\begin{array}{c}\text { mgm. } \\
\text { per } \\
\text { day } \\
1.5 \\
2.3\end{array}$ & $\begin{array}{c}\text { mgm. per } \\
\text { day } \\
1.1 \text { to } 1.8 \\
0.7 \text { to } 0.8\end{array}$ & $\begin{array}{c}\text { mgm. } \\
\text { per } \\
\text { day } \\
1.5 \\
0.7\end{array}$ \\
\hline G. $\mathbf{P}$. & $\mathbf{F}$ & 31 & Acute enteritis & 40.5 & 3 & Symptomatic & C. $\mathbf{T}$. & 1.2 to 6.0 & 3.6 & 0.6 to 3.0 & 2.1 & 1.0 & 1.0 \\
\hline B. $\mathbf{H}$. & $\mathbf{F}$ & 19 & Acute tonsillitis & 39.8 & 3 & Sulfadiazine & L. G. & $<0.5$ to 3.7 & 2.1 & $<0.5$ to 0.5 & 0.5 & & \\
\hline M. B. & $\mathbf{F}$ & 20 & Acute pharyngitis & 39.2 & 7 & Symptomatic & L. $\mathbf{G}$. & $<0.5$ to 0.5 & 0.5 & $<0.5$ to 1.2 & 0.8 & & \\
\hline E. H. & $\mathbf{M}$ & 31 & Typhoid fever & 41.0 & 24 & Symptomatic & L. G. & 0.7 to 3.4 & 2.0 & 0.4 to 0.8 & 0.7 & & \\
\hline J. B. & $\mathbf{M}$ & 25 & Lobar pneumonia & 40.2 & 1 & Penicillin & L. G. & 0.4 & 0.4 & 0.4 to 1.5 & 0.7 & & \\
\hline V. L. & $\mathbf{M}$ & 19 & $\begin{array}{l}\text { Fulminating } \\
\text { meningococcemia }\end{array}$ & 40.0 & 1 & Penicillin & L. $\mathbf{G}$. & 0.6 & 0.6 & & & & \\
\hline
\end{tabular}

* Cold test.

$\dagger$ Liver glycogen test.

The febrile period was defined as the active phase of the disease; the first week after fever subsided was considered to be the phase of early convalescence; and the second week, late convalescence. 
Urinary cortin as influenced by infection. Seven patients with infectious disease were studied. The findings are tabulated in Table II. Five of the patients showed increases in excretion during the febrile, or early post-febrile stages, which were higher than levels encountered in normal subjects. The 2 patients which showed no augmentation in output were ill for only 1 day. One (J. B.) was a very early case of lobar pneumonia promptly aborted with penicillin, and the other (V. L.) was a patient with fulminating meningococcemia who died within 24 hours after onset. The latter case is of some interest inasmuch as the patient was admitted in shock and fulfilled all of the clinical qualifications of the Waterhouse-Friderichsen syndrome. The presence of a normal level of urinary cortin argues that the shock was not due to adrenal insufficiency. An autopsy could not be obtained.

During the period of early convalescence, the 4 patients who had excreted increased amounts of cortin during the febrile stage showed a decline to normal or slightly hypernormal levels. In late convalescence the 2 patients who were followed showed normal levels of excretion. In no case was there any consistent decline to subnormal levels during the period of convalescence. Patients $B$. H. and E. H. experienced post-infectious asthenia during the early convalescent period, but their cortin excretion during this time did not differ from that of the other patients.

Cortin excretion as affected by surgery. Two patients undergoing herniorrhaphy were studied (Table III). Assays were done on patient C. D. for a 48-hour period at home before admission to the hospital, and for another 48 hours pre-operatively while he was confined to bed. An ambulatory control period was not included in the case of patient J. W. In both cases there was a distinct rise in excretion during the first 2 to 4 days post-operatively. Patient J. W. showed an increase more than 10 -fold above his pre-operative level. After 6 days the levels in both cases had returned to normal. There were no post-operative complications. It should be noted that patient C. D. received a local anesthetic, and that the response in this instance may therefore be attributed to the surgical procedure per se.

Cortin excretion after body burns. This group included 3 patients (Table IV). The 1 patient (M. D.) who recovered was studied over a fairly long period of convalescence. There was an unmistakable rise in cortin excretion during the first 8 days after the burn. By the end of 12 days the elevation was less marked, and beyond 12 days the values had declined to within the range of normal. Patient C. D. showed a moderate elevation shortly before his death on the ninth day. Patient A. T., who also died, did not excrete quantities of cortin in excess of the values normally encountered.

The results herein reported confirm and extend the original findings of Weil and Browne. Venning and Browne (14), furthermore, have recently demonstrated a rise in urinary cortin during stress when assays were performed by a glycogen method. Our most formidable hurdle has been the development of quantitative assay methods possessing sufficient simplicity and reliability to be applied to clinical cases. Methods which are now available still leave much to be desired. It is possible, however, that further refinement of the glycogen procedure will render it reasonably satisfactory for this purpose. Talbot and coworkers (15) have recently devised a chemical procedure for the assay of adrenal cor-

TABLE III

Cortin excretion after herniorrhaphy

\begin{tabular}{|c|c|c|c|c|c|c|c|c|c|c|c|c|c|}
\hline \multirow{3}{*}{ Case } & \multirow{3}{*}{ Sex } & \multirow{3}{*}{ Age } & \multirow{3}{*}{ Operation } & \multirow{3}{*}{$\begin{array}{l}\text { Anes- } \\
\text { thetic }\end{array}$} & \multirow{3}{*}{$\begin{array}{c}\text { Type } \\
\text { of } \\
\text { Assay }\end{array}$} & \multicolumn{8}{|c|}{ Cortin excretion compound A equiv. } \\
\hline & & & & & & \multicolumn{2}{|c|}{ Preoperative } & \multicolumn{6}{|c|}{ Postoperative day } \\
\hline & & & & & & $\underset{\text { tory }}{\text { Ambula- }}$ & $\underset{\text { bed }}{\text { In }}$ & 1 to 2 & 3 to 4 & 5 to 6 & 7 to 8 & 9 to 10 & 11 to 12 \\
\hline C. D. & $\mathbf{M}$ & 35 & $\begin{array}{l}\text { Bilateral } \\
\text { herniorrhaphy }\end{array}$ & Local & C. $\mathrm{T}$. & 1.6 & 0.5 & 2.3 & 3.0 & $\begin{array}{c}m g m . \\
1.9\end{array}$ & $\begin{array}{c}\text { er day } \\
0.9\end{array}$ & 1.1 & 0.6 \\
\hline J.W. & $\mathbf{M}$ & 26 & $\begin{array}{l}\text { Rt. inguinal } \\
\text { herniorrhaphy }\end{array}$ & Ether & L. G. & & $<0.5$ & 4.9 & & 0.5 & & 0.8 & \\
\hline
\end{tabular}


TABLE IV

Cortin excretion in the presence of body burns

\begin{tabular}{|c|c|c|c|c|c|c|c|c|c|c|c|c|c|c|}
\hline \multirow{2}{*}{ Case } & \multirow{2}{*}{ Sex } & \multirow{2}{*}{ Age } & \multirow{2}{*}{$\begin{array}{c}\text { Percent } \\
\text { body } \\
\text { area }\end{array}$} & \multirow{2}{*}{$\begin{array}{c}\text { Type } \\
\text { of } \\
\text { assay }\end{array}$} & \multicolumn{10}{|c|}{$\begin{array}{l}\text { Cortin excretion compound A equiv. } \\
\text { Days after burn }\end{array}$} \\
\hline & & & & & 1 to 4 & 5 to 8 & 9 to 12 & 13 to 16 & 17 to 20 & 21 to 24 & 25 to 28 & 29 to 32 & 33 to 36 & 90 \\
\hline C. D. & $\mathbf{M}$ & 46 & 50 & C. T. & \multicolumn{10}{|c|}{ mgm. per day } \\
\hline A. $T$. & $\mathbf{M}$ & 48 & 30 & L. G. & 0.6 & 0.8 & $<0.5$ & Died & & & & & & \\
\hline M. D. & $\mathbf{F}$ & 26 & 50 & L. G. & 3.5 & 3.7 & 1.4 & & 0.7 & & 0.7 & & 0.5 & $<0.3$ \\
\hline
\end{tabular}

We are indebted to Dr. W. E. Abbott of the Department of Surgery, Wayne University, for the urine specimens on A. T. and M. D.

tical steroids in urine. The advantages of a chemical method are obvious, but interpretations of results must be made with caution until the compounds which take part in the reaction have been identified, or until it has been shown that values obtained by the chemical method correlate with those derived by bioassay.

It is apparent that the amount of cortin-like material present in normal human urine is fairly large. Without doubt the values which were obtained are minimal estimates. The urine was extracted with solvent only 3 times. Further extraction both before or after hydrolysis has been shown to yield additional quantities of active material. It is of interest to note that the chemical estimate of corticosteroid excretion obtained by Talbot in normal subjects is not far from the values we have secured by bioassay.

It is reasonable to assume that the increased cortin output during stress is a reflection of increased cortical hormone production. Other possible interpretations are a decreased tissue affinity for the hormone, an increase in the rate of renal excretion, or a decreased inactivation. It is unlikely that decreased tissue affinity or increased excretion could be responsible for the augmented output. The possibility of decreased inactivation could be more easily defended, however.

Adrenal cortical hypersecretion would fit very nicely into the pattern of physiological readjustment which is known to result from the stimulus of stress. Selye was the first to emphasize that the organism reacts in identical fashion to a variety of damaging stimuli (16). He emphasized, moreover, that the adrenal cortex was probably of prime importance in the facilitation of adjustment. In order to simplify discussion, some of the possible physiological and clinical implications of cortical hyperfunction during stress are outlined in tabular form (Table V). Albright (17) has recently discussed a number of these mechanisms.

If one assumes that increased cortical secretion during stress is beneficial to the organism, it follows that any failure in this function should influence the course of recovery. If it can be shown that in some cases of infection or other stress a low output of cortin is associated with a higher mortality or a delay in recovery, it would be justifiable to administer cortical hormone to such patients. Such a correlation has as yet not been made, however, and evidence does not exist that in the absence of specific adrenal disease hypo-

TABLE $V$

Possible functions of adrenal cortical hormone during stress

\begin{tabular}{l|l|l|l}
\hline \hline \multicolumn{1}{c|}{ Observed changes } & \multicolumn{1}{|c|}{ Physiological aspects } & \multicolumn{1}{c|}{ Beneficial aspect } & \multicolumn{1}{c}{ Possible disadvantage } \\
\hline $\begin{array}{l}\text { Negative nitrogen } \\
\text { balance } \\
\text { Hyperglycemia }\end{array}$ & $\begin{array}{l}\text { Increased gluconeo- } \\
\text { genesis }\end{array}$ & $\begin{array}{l}\text { Source of endogenous } \\
\text { carbohydrate }\end{array}$ & $\begin{array}{l}\text { Wastage of protoplasm in prolonged } \\
\text { disease. } \\
\text { ance in presence of diabetes }\end{array}$ \\
$\begin{array}{l}\text { Tendency to retain salt } \\
\text { and water }\end{array}$ & $\begin{array}{l}\text { Increased reabsorption } \\
\text { of sodium by kidney }\end{array}$ & $\begin{array}{l}\text { Support of plasma } \\
\text { volume }\end{array}$ & $\begin{array}{l}\text { Hemodilution and edema after admin- } \\
\text { istration of large quantities of saline }\end{array}$ \\
\hline \begin{tabular}{l} 
Lysis of lymphoid tissue \\
\hline
\end{tabular} & Release of antibodies & Defense against infection & \\
\hline
\end{tabular}


function of the gland is a factor in recovery from stress.

\section{SUM MARY AND CONCLUSIONS}

1. In normal subjects the daily excretion of urinary cortin averaged about $1.1 \mathrm{mgm}$. of compound A-equivalent per day when assayed biologically by a cold protection test, and $<0.4 \mathrm{mgm}$. per day by a glycogen deposition test. There was no obvious difference in the output of male and female subjects.

2. In the presence of infectious disease, after body burns, and during the first 2 days after herniorrhaphy, the output of urinary cortin was usually increased above the control levels. The rise in some instances was as high as 10 -fold.

3. During recovery from stress there was no abnormal depression in output which one would expect in the presence of adrenal exhaustion.

\section{BIBLIOGRAPHY}

1. Tepperman, J., Engel, F. L., and Long, C. N. H., A review of adrenal cortical hypertrophy. Endocrinology, 1943, 32, 373.

2. Sarason, E. L., Adrenal cortex in systemic disease. Arch. Int. Med., 1943, 71, 702.

3a. Weil, P., and Browne, J. S. L., The excretion of cortin after surgical operation. Science, 1939, 90, 445.

b. Ibid., Excretion of cortin under conditions of damage. J. Clin. Invest., 1940, 19, 772.

4. Dorfman, R. I., Horwitt, B. N., and Fish, W. R., The presence of a cortin-like substance (cold protecting material) in the urine of normal men. Science, 1942, 96, 496.

5. Dorfman, R. I., and Horwitt, B. N., Maintenance of adrenalectomized rats with urinary extracts. Fed. Proc., 1943, 2, 60.
6. Venning, E. H., Hoffman, M. M., and Browne, J. S. L., The life maintaining and gluconeogenic properties of the cortin-like material excreted postoperatively. J. Biol. Chem., 1943, 148, 455.

7. Shipley, R. A., Dorfman, R. I., and Horwitt, B. N., The presence in normal urine of cortin-like material which is active in a muscle work test. Am. J. Physiol., 1943, 139, 742.

8. Horwitt, B. N., and Dorfman, R. I., The effect of urinary cortin-like material on carbohydrate metabolism. Science, 1943, 97, 337.

9. Schiller, S., and Dorfman, R. I., Influence of urinary cortin-like material on water intoxication in the adrenalectomized rat. Endocrinology, 1943, 33, 402.

10. Dorfman, R. I., Horwitt, B. N., Shipley, R. A., and Abbott, W. E., The metabolism of steroid hormones; the adrenal gland as the source of cortinlike material in the urine of monkeys. Endocrinology, 1944, 35, 15.

11. Dorfman, R. I., Horwitt, B. N., and Shipley, R. A., The metabolism of steroid hormones; adrenal cortical-like material in human urine. Endocrinology, 1944, 35, 121.

12. Dorfman, R. I., Ross, E., and Shipley, R. A., The assay of adrenal cortical material by means of a glycogen test in the adrenalectomized mouse. Endocrinology, 1946, 38, 178.

13. Dorfman, R. I., Shipley, R. A., Schiller, S., and Horwitt, B. N., Studies on the "Cold Test" as a method for the assay of adrenal cortical steroids. Endocrinology, 1946, 38, 165.

14. Venning, E. H., and Browne, J. S. L., Excretion of urinary corticoid hormones. Fed. Proc., 1945, 4, 108.

15. Talbot, N. B., Saltzman, A. H., Wixom, R. L., and Wolfe, J. K., The colorimetric assay of urinary corticosteroid-like substances. J. Biol. Chem., 1945, $160,535$.

16. Selye, $H$., The alarm reaction. The Cyclopedia of Medicine, Surgery and Specialties. 1940, 15, 15.

17. Albright, F., Cushing's Syndrome. Harvey Lect., 1943, 38, 123. 